\title{
INFLUENCE OF MOISTURE AND TEMPERATURE ON THE THERMAL PROPERTIES OF JACK BEAN SEEDS (CANAVALIA ENSIFORMIS)
}

Oriola K. Olaniyi ${ }^{1}$, Hussein J. Babatunde ${ }^{* 2}$, Oke M. Olanrewaju ${ }^{3}$, Ajetunmobi Abimbola ${ }^{1}$

${ }^{1}$ Ladoke Akintola University of Technology, Faculty of Engineering and Technology, Department of Agricultural Engineering, PMB 4000 Ogbomoso, Oyo State, Nigeria

${ }^{2}$ Modibbo Adama University of Technology, Faculty of Agriculture, Department of Food Science and Technology, PMB 2076 Yola, Adamawa State, Nigeria

${ }^{3}$ Ladoke Akintola University of Technology, Faculty of Engineering and Technology, Department of Food Engineering, PMB 400 Ogbomoso, Oyo State, Nigeria

\begin{abstract}
The thermal properties (specific heat capacity, thermal conductivity, and thermal diffusivity) of Jack bean seed (Canavalia ensiformis) were determined for designing the equipment necessary for thermal processes. These thermal properties were determined at $5,10,15,20$, and 25 $\%$ moisture contents and temperatures at 30,40 , and $50{ }^{\circ} \mathrm{C}$ using the $\mathrm{KD} 2$ Pro thermal analyzer. Results showed that the specific heat capacity ranged from 1.55 to $2.47 \mathrm{~kJ} / \mathrm{kgK}, 1.26$ to 1.84 $\mathrm{kJ} / \mathrm{kgK}$ and 1.32 to $1.99 \mathrm{~kJ} / \mathrm{kgK}$; thermal conductivity 0.21 to $0.47 \mathrm{~W} / \mathrm{mK}, 0.34$ to $0.52 \mathrm{~W} / \mathrm{mK}$, and 0.26 to $0.60 \mathrm{~W} / \mathrm{mK}$ and thermal diffusivity 0.25 to $0.41 \times 10^{-7} \mathrm{~m}^{2} / \mathrm{s}, 0.32$ to $0.57 \times 10^{-7} \mathrm{~m}^{2} / \mathrm{s}$, and 0.32 to $0.60 \times 10^{-7} \mathrm{~m}^{2} / \mathrm{s}$ at 30,40 , and $50{ }^{\circ} \mathrm{C}$ respectively for the moisture ranges studied. The temperature and moisture content effects were not significant $(p>0.05)$ with specific heat and thermal diffusivity but were significant $(p<0.05)$ with thermal conductivity in third-order polynomial. A non-linear relationship was established between the three thermal properties and moisture content within the studied temperature range. The resulting regression models for the thermal properties gave a high coefficient of determination $\left(R^{2} \geq 0.7995\right)$ which implies that the parameters can be used to describe the relationships between temperature, moisture, and thermal properties of Jack bean seeds.
\end{abstract}

Key words: Jack beans, legume, moisture, temperature, thermal properties, thermal analyzer

\section{INTRODUCTION}

Jack bean (Canavalia ensiformis) is a tropical leguminous plant with a high yield of seeds and foliage. The plant is native to tropical Africa, Central and South America, Southern Mexico, Brazil, Peru, and West Indian (Ranjeet, Singh, Va-run, Mallesha \& Raju, 2016). Osuigwe, Obiekezie and Onuoha (2006) reported that ma- ture Jack bean seed has high crude protein content $(20-32 \%)$ and amino-acid profile that makes it suitable for use as a substitute for fish feed while the fully ripened seeds are sometimes used as a coffee substitute. Marimuthu and Gurumoorthi (2013) also reported that raw Jack bean seeds contain about $300 \mathrm{~g} / \mathrm{kg}$ protein 
and $600 \mathrm{~g} / \mathrm{kg}$ carbohydrates which make it a greater potential source of dietary proteins. Akpapunam and Sefa-Dedeh (1997) reported that Jack bean seeds protein content ranges from 23.40 to $34.80 \%$ and starch 29.50 to $34.90 \%$ on a dry weight basis. Jack beans, like other legumes, have nutritionally adequate levels of most essential amino acids with the exception of sulfur amino acids, methionine, and cysteine (Michael, Sogbesan \& Onyia, 2018).

To fulfill the growing demands of plant-based proteins for humans and livestock need, research on the possibilities of employing Jack bean seed as a source of protein has been explored for their nutritional advantages (Gabriel, Akinyosoye \& Adetuyi, 2011; Ranjeet et al., 2016). However they possess some anti-nutritional factors (trypsin and chemyotrypsin inhibitors, antivitamin, tannin, lectin, phytic acid, cyanogens, and saponin, etc.) which make their utilization very difficult, hence the need for their heat treatments. Embaby (2010) and Arinola and Adesina (2014) reported a considerable decrease or elimination in the anti-nutrient of the seeds after heat processing (boiling, extrusion, autoclaving, microwave, roasting). However, heat processing also has a detrimental effect on the nutritional and functional properties of foods. Therefore, there is a need to establish the thermal properties of the food optimum to develop the thermal processes and equipment needed for storage, drying, heating, and cooling. Bart-Plange, Addo and Piegu, (2012) reported that the knowledge of the thermal properties of food and agricultural products is essential for equipment design and prediction of heat transfer operations. Oriola, Oke, Hussein and Adebesin (2016) also stated that the thermal properties of food and agricultural materials are necessary knowledge needed for the effecttive design of food processing equipment such as heat exchangers and other equipment which require pumping of the products.

The thermal properties of various foods and agricultural products have been studied by many researchers such as Chakraborty and Johnson (1999) for Tobaco, Chandrasekar and Viswanathan (1999) for coffee, Aviara, Haque and Ogunjimi (2008) for guna seeds and Tansakul and Lumyong (2008) for straw mushroom. Also, moisture and temperature dependency of thermal properties of some food crops have been studied by other researchers such Aviara and Haque (2001) for shea nut kernel, Bart-
Plange et al. (2012) for cashew kernel, Gharibzahedi, Ghahderijani and Lajevardi (2013) for red lentil seed, Isa, Oladele and Akinlade (2014) for egusi melon and Oriola et al. (2016) for cooked locust bean seeds. Oriola, Hussein, Oke and Ajetunmobi (2020) evaluated the physical and moisture dependent thermal properties of Jack bean seeds. However, extensive literature search revealed a paucity publication on the simultaneous effect of moisture content and temperature on the thermal properties of Jack bean seed. Thus, the objective of the study was to determine the effect of moisture content and temperature on the thermal properties of the Jack bean seed. The availability of such relevant information on Jack bean seeds will help in the design and manufacture of equipment for its postharvest operations.

\section{MATERIALS AND METHODS}

\section{Samples collection}

Mature Jack bean pods were sourced from the Genetic Resources Unit of International Institute of Tropical Agriculture (IITA) Ibadan, Oyo State Nigeria. The pods were manually threshed to obtain the Jack bean seeds. The moisture analysis method described by Oriola et al. (2016) was used to determine the initial moisture content of the Jack bean seed.

\section{Determination of thermal properties}

A KD2 Pro thermal properties analyzer (Decagon KD2 Pro, NE Hopkins CT Pullman, WA 99163 USA) was used to determine the specific heat capacity $(\mathrm{Cp})$, thermal conductivity $(\mathrm{k})$, and thermal diffusivity $(\alpha)$. Jack bean seeds were weighed into the sample holder and the probe of the analyzer was inserted through the lid. The transient line heat source method was used to determine these thermal properties simultaneously as described by Oriola (2014) and Oriola et al. (2016). The Jack bean samples (100 g each) were conditioned to five different moisture contents of $5,10,15,20$, and $25 \%$ (wet basis) after determining the initial moisture content using an OAHM 60 digital moisture analyzer (MD7822 Model) as described by Oriola et al. (2016). The moisture content of samples whose initial moisture content was less than the required was raised by ad-ding an appropriate quantity of distilled water as determined using Equation 1 while those with initial moisture content above the required were dried to the appropriate moisture level as deter- 
mined by using Equation 2. Thereafter, the samples were poured into polyethylene bags, sealed tightly, and conditioned in a refrigerator for $24 \mathrm{~h}$ for moisture equilibration.

$$
Q=\frac{w_{i}\left(m_{f}-m_{i}\right)}{100-m_{f}}
$$

where:

$\mathrm{Q}=$ Mass of water added

$\mathrm{w}_{\mathrm{i}}=$ Mass of sample

$\mathrm{m}_{\mathrm{f}}=$ Final moisture content

$\mathrm{m}_{\mathrm{i}}=$ Initial moisture content

$M C=\frac{M_{w}-M_{d}}{M_{w}}$

where;

$\mathrm{MC}=$ Final moisture content of sample

being dried

$\mathbf{M}_{\mathrm{w}}=$ Initial mass of wet sample

$\mathrm{M}_{\mathrm{d}}=$ Final mass of sample being dried

The samples holder was loaded with a known quantity of Jack bean seeds and the $\mathrm{SH}-1$ probe gang was selected and inserted through the lid of the sample holder and the thermal properties were determined at an average room temperature of $30^{\circ} \mathrm{C}$ at each moisture level. The experiments at $30^{\circ} \mathrm{C}$ were replicated five times for each moisture content level. Thereafter, the experiments were repeated at sample temperatures of 40 and $50{ }^{\circ} \mathrm{C}$ respectively using a thermostatic water bath (DK-2000-ISL) to rise the temperature of the samples before the experiments was conducted.

\section{Statistical analysis}

Data analysis was conducted using SPSS ${ }^{\circledR}$ version 20 (Statistical Package for Social Sciences, USA). The significance of the difference between the means was determined using Duncan's Multiple Range Test, and the differences were considered to be significant at $\mathrm{p}<0.05$. Microsoft Excel spreadsheet software version 2013 was used to do all the experimental calculations. The STAT-EASE DESIGN EXPERT 11.1.2.0 software was used for the regression analysis of the experimental data.

\section{RESULTS AND DISCUSSION}

\section{Specific heat capacity (Cp) of Jack bean seeds}

The variation of specific heat capacity of Jack bean seeds with moisture content at different temperatures was presented in Table 1 . The $\mathrm{Cp}$ of ranged from 1.55 to $2.47 \mathrm{~kJ} / \mathrm{kgK}, 1.26$ to 1.84
$\mathrm{kJ} / \mathrm{kgK}$ and 1.324 to $1.988 \mathrm{~kJ} / \mathrm{kgK}$ for $30^{\circ} \mathrm{C}, 40^{\circ}$ $\mathrm{C}$ and $50^{\circ} \mathrm{C}$ temperatures respectively. There were no significant differences $(p>0.05)$ in the $\mathrm{Cp}$ as moisture content increases from 5 to $25 \%$, however, there were increases in the mean values of $\mathrm{Cp}$ as moisture content increases. A similar trend of increase was reported by Abioye, Adekunle and Agbasi-Ebere (2016) for Bambara groundnut and Oriola et al. (2016) for cooked locust bean seed. An increase in $\mathrm{Cp}$ with increasing moisture content as observed in this study may be due to the high $\mathrm{Cp}$ of water compared to the dry material and the water occupying the air-filled pores faster at lower moisture contents (Sadiku \& Bamgboye, 2014). The high specific heat obtained for these seeds implies that a thousand Joules of heat energy is required to raise or lower the temperature of seeds by $1{ }^{\circ} \mathrm{C}$.

The polynomial functions for the simultaneously dependence of temperature and moisture content on the $\mathrm{Cp}$ were presented in Fig. 1. The $\mathrm{Cp}$ was even observed to rise sharply when the moisture was increased beyond $15 \%$ wet basis (wb). A similar trend was observed at an elevated temperature of $50^{\circ} \mathrm{C}$ but with lower $\mathrm{Cp}$ values. However, at a temperature of $40{ }^{\circ} \mathrm{C}$, a sharp nonlinear negative (falling) trend was observed within the moisture range from 5 to $15 \%$ beyond which a gentle non-definite trend was observed. Also, at low moisture level, Cp initially increased with temperature and peaked at $40{ }^{\circ} \mathrm{C}$ then least at $50{ }^{\circ} \mathrm{C}(1.6 \mathrm{~kJ} / \mathrm{kgK})$. An opposite trend was, however, observed at elevated moisture condition $(25 \% \mathrm{wb})$ as the $\mathrm{Cp}$ was least at $40{ }^{\circ} \mathrm{C}$ and highest $(2.4 \mathrm{~kJ} / \mathrm{kgK})$ at $30{ }^{\circ} \mathrm{C}$. A non- linear relationship of $\mathrm{Cp}$ with moisture contents was also been reported by Oriola (2014) for cassava root and Oriola et al. (2016) for cooked locust bean seed. However, other studies have reported a linear relationship such as Hsu, Mannapperuma and Singh (1991) for pistachios, Bart-Plange et al. (2012) for cashew kernel, Chandrasekar and Viswanathan (1999) for coffee beans, and Abioye et al. (2016) for Bambara groundnut. This shows that the food materials to be processed determine the type of heat processing it needs to be subjected to (Oriola et al., 2020). Therefore, the results obtained for the specific heat capacity of these Jack beans seeds will be useful in determining the heat energy required for each stage of the process and the optimization of the process to reduce the boiling duration to the barest mi- 
nimum. This in turn will help in the retention of nutrients and energy savings. Table 2 shows the Jack bean seeds temperature, moisture content and specific heat capacity relationships in a second-order polynomial equation. The best fit resulting in an $\mathrm{R}^{2}$ value of 0.7995 was obtained. This is suggesting that the regression equation can be used to describe the relationships between the temperature, moisture, and the $\mathrm{Cp}$ of the Jack bean seeds. Koocheki, Taherian, Razavi and Bostan (2009) reported that $\mathrm{R}^{2}$ should not be less than 0.80 for a well-fitted model, while $\mathrm{R}^{2}$ greater than 0.75 was reported acceptable for fitting a model by Chauhan and
Gupta (2004). Singh and Goswami (2000) and Razavi and Taghizadeh (2007) investigations revealed that the specific heat of cumin seed and four varieties of Iranian pistachio were also dependent on both moisture and temperature and increased as a second-order linear and nonlinear polynomial respectively. Analysis of variance (ANOVA) showed the effect of individual and combined independent variables on the thermal properties (Table 3).

The P-value of the models less than $0.05 \%$ showed that the models were significant and confirmed the adequacy and effect of each variable.

Table 1

Thermal properties of Jack bean seeds

\begin{tabular}{|c|c|c|c|c|}
\hline $\begin{array}{c}\text { Temperature } \\
\left({ }^{\circ} \mathrm{C}\right)\end{array}$ & $\begin{array}{c}\text { Moisture } \\
\text { content } \\
(\%)\end{array}$ & $\begin{array}{c}\text { Specific heat capacity } \\
\qquad(\mathrm{kJ} / \mathrm{kgK})\end{array}$ & $\begin{array}{c}\text { Thermal } \\
\text { conductivity } \\
(\mathrm{W} / \mathrm{m} . \mathrm{K})\end{array}$ & $\begin{array}{l}\text { Thermal diffusivity } \\
\qquad\left(\mathrm{m}^{2} / \mathrm{s}\right) \times 10^{-7}\end{array}$ \\
\hline \multirow{5}{*}{30} & 5 & $1.62 \pm 0.27^{\mathrm{b}}$ & $0.21 \pm 0.07^{\mathrm{d}}$ & $0.25 \pm 0.01^{\mathrm{d}}$ \\
\hline & 10 & $1.55 \pm 0.26^{\mathrm{b}}$ & $0.27 \pm 0.07^{\mathrm{cd}}$ & $0.32 \pm 0.04^{\mathrm{cd}}$ \\
\hline & 15 & $1.57 \pm 0.21^{\mathrm{b}}$ & $0.42 \pm 0.05^{\mathrm{abcd}}$ & $0.41 \pm 0.05^{\mathrm{abcd}}$ \\
\hline & 20 & $1.99 \pm 0.15^{\mathrm{ab}}$ & $0.47 \pm 0.07^{\mathrm{abc}}$ & $0.34 \pm 0.04^{\mathrm{cd}}$ \\
\hline & 25 & $2.47 \pm 0.45^{\mathrm{a}}$ & $0.38 \pm 0.07^{\mathrm{abcd}}$ & $0.25 \pm 0.04^{\mathrm{d}}$ \\
\hline \multirow{5}{*}{40} & 5 & $1.84 \pm 0.27^{\mathrm{ab}}$ & $0.39 \pm 0.10^{\mathrm{abcd}}$ & $0.32 \pm 0.03^{\mathrm{cd}}$ \\
\hline & 10 & $1.74 \pm 0.30^{\mathrm{ab}}$ & $0.52 \pm 0.11^{\mathrm{ab}}$ & $0.49 \pm 0.11^{\mathrm{abc}}$ \\
\hline & 15 & $1.26 \pm 0.10^{\mathrm{b}}$ & $0.52 \pm 0.08^{\mathrm{ab}}$ & $0.57 \pm 0.07^{\mathrm{ab}}$ \\
\hline & 20 & $1.47 \pm 0.15^{\mathrm{b}}$ & $0.56 \pm 0.07^{\mathrm{abcd}}$ & $0.38 \pm 0.01^{\mathrm{bcd}}$ \\
\hline & 25 & $1.28 \pm 0.12^{\mathrm{b}}$ & $0.34 \pm 0.03^{\mathrm{bcd}}$ & $0.44 \pm 0.05^{\mathrm{abcd}}$ \\
\hline \multirow{5}{*}{50} & 5 & $1.48 \pm 0.19^{b}$ & $0.26 \pm 0.07^{\mathrm{cd}}$ & $0.33 \pm 0.06^{\mathrm{cd}}$ \\
\hline & 10 & $1.77 \pm 0.05^{\mathrm{ab}}$ & $0.54 \pm 0.06^{\mathrm{ab}}$ & $0.42 \pm 0.04^{\mathrm{abcd}}$ \\
\hline & 15 & $1.45 \pm 0.21^{\mathrm{b}}$ & $0.60 \pm 0.06^{\mathrm{a}}$ & $0.60 \pm 0.10^{\mathrm{a}}$ \\
\hline & 20 & $1.32 \pm 0.13^{\mathrm{b}}$ & $0.34 \pm 0.07^{\mathrm{bcd}}$ & $0.44 \pm 0.11^{\mathrm{abcd}}$ \\
\hline & 25 & $1.99 \pm 0.27^{\mathrm{ab}}$ & $0.39 \pm 0.07^{\mathrm{abcd}}$ & $0.32 \pm 0.06^{\mathrm{cd}}$ \\
\hline
\end{tabular}

Means within the same column at each temperature with different superscripts are significantly different $(p<0.05)$

Table 2

Polynomial regression model equations

\begin{tabular}{lc}
\hline Equations & $\mathbf{R}^{2}$ \\
\hline$C_{p}=1.310-0.080 x_{1}-0.278 x_{2}-0.157 x_{1} x_{2}+0.203 x_{1}^{2}+0.282 x_{2}^{2}+0.549 x_{1}^{2} x_{2}-$ & 0.7995 \\
$0.079 x_{1} x_{2}^{2}$ & \\
$k=0.492+0.065 x_{1}-0.160 x_{2}-0.263 x_{1} x_{2}-0.019 x_{1}^{2}-0.131 x_{2}^{2}+0.112 x_{1}^{2} x_{2}-$ & 0.9405 \\
$0.054 x_{1} x_{2}^{2}+0.127 x_{2}^{3}-0.037 x_{1}^{2} x_{2}^{2}+0.253 x_{1} x_{2}^{3}$ & \\
$\alpha=0.522+0.074 x_{1}+0.026 x_{2}-0.002 x_{1} x_{2}-0.072 x_{1}^{2}-0.167 x_{2}^{2}-0.024 x_{1}^{2} x_{2}-$ & 0.7997 \\
$0.040 x_{1} x_{2}^{2}$ &
\end{tabular}

$x_{1}=$ Temperature $\left({ }^{\circ} \mathrm{C}\right) ; x_{2}=$ Moisture content $(\%)$ 
Table 3

Analysis of variance for effect of temperature and moisture content on the thermal property of Jack bean seeds

\begin{tabular}{|c|c|c|c|c|c|c|c|c|c|}
\hline \multirow{2}{*}{$\begin{array}{c}\begin{array}{l}\text { Polynomial } \\
\text { regression }\end{array} \\
\text { Source }\end{array}$} & \multicolumn{3}{|c|}{$\begin{array}{c}\text { Specific heat capacity } \\
(\mathrm{KJ} / \mathrm{kgK})\end{array}$} & \multicolumn{3}{|c|}{$\begin{array}{l}\text { Thermal conductivity } \\
(\mathrm{W} / \mathrm{mK})\end{array}$} & \multicolumn{3}{|c|}{$\begin{array}{c}\text { Thermal diffusivity } \\
\left(\mathrm{m}^{2} / \mathrm{s}\right)\end{array}$} \\
\hline & $\begin{array}{l}\text { Sum of } \\
\text { Squares }\end{array}$ & Df & p-value & $\begin{array}{c}\text { Sum of } \\
\text { Squares }\end{array}$ & Df & p-value & $\begin{array}{c}\text { Sum of } \\
\text { Squares }\end{array}$ & Df & p-value \\
\hline Model & 1.18 & 7 & 0.04 & 0.17 & 10 & 0.05 & 0.12 & 7 & 0.04 \\
\hline $\begin{array}{l}\text { A- } \\
\text { Temperature } \\
\left({ }^{\circ} \mathrm{C}\right)\end{array}$ & 0.03 & 1 & 0.46 & 0.02 & 1 & 0.06 & 0.02 & 1 & 0.06 \\
\hline $\begin{array}{l}\text { B-Moisture } \\
\text { content }(\%)\end{array}$ & 0.19 & 1 & 0.07 & 0.02 & 1 & 0.06 & 0 & 1 & 0.55 \\
\hline AB & 0.12 & 1 & 0.13 & 0.04 & 1 & 0.02 & 0 & 1 & 0.95 \\
\hline $\mathbf{A}^{2}$ & 0.14 & 1 & 0.12 & 0 & 1 & 0.68 & 0.02 & 1 & 0.09 \\
\hline $\mathbf{B}^{2}$ & 0.21 & 1 & 0.06 & 0.02 & 1 & 0.07 & 0.07 & 1 & 0.01 \\
\hline $\mathbf{A}^{2} \mathbf{B}$ & 0.5 & 1 & 0.01 & 0.02 & 1 & 0.05 & 0 & 1 & 0.65 \\
\hline $\mathbf{A B}^{2}$ & 0.01 & 1 & 0.63 & 0.01 & 1 & 0.23 & 0 & 1 & 0.45 \\
\hline $\mathbf{B}^{3}$ & - & - & - & 0.01 & 1 & 0.11 & - & - & - \\
\hline $\mathbf{A}^{2} \mathbf{B}^{2}$ & - & - & - & 0 & 1 & 0.61 & - & - & - \\
\hline $\mathbf{A B}^{\mathbf{3}}$ & - & - & - & 0.03 & 1 & 0.03 & - & - & - \\
\hline Residual & 0.3 & 7 & & 0.01 & 4 & & 0.03 & 7 & \\
\hline Total & 1.48 & 14 & & 0.18 & 14 & & 0.15 & 14 & \\
\hline
\end{tabular}

The ANOVA indicated that model terms are significant (p-values less than 0.05 ) and a greater effect of the moisture content than that of the temperature on the specific heat capacity.

\section{Thermal conductivity (k) of Jack bean seeds}

Table 1 presented the results of the thermal conductivity of Jack bean seeds at different moisture contents and temperatures. The thermal conductivity varied from 0.21 to $0.47 \mathrm{~W} / \mathrm{mK}$, 0.34 to $0.39 \mathrm{~W} / \mathrm{mK}$, and 0.26 to $0.60 \mathrm{~W} / \mathrm{mK}$ for 30,40 , and $50{ }^{\circ} \mathrm{C}$ temperatures respectively. These values are slightly higher than the 0.21 to $0.23 \mathrm{~W} / \mathrm{mK}$ and 0.25 to $0.31 \mathrm{~W} / \mathrm{mK}$ reported by Bart-Plange et al. (2012) and Abioye et al. (2016) respectively for cashew kernel and Bambara groundnut. However, they are within the range of 0.02 to $0.62 \mathrm{~W} / \mathrm{mK}$ for unfrozen food products as reported by Carson (2017). This means that the heat conductors and energy transfers of Jack bean seed during cooling, drying, and related operations are better than those of cashew kernel, Bambara groundnut, and other crops with lesser thermal conductivity.

Fig. 2 represents the surface plot showing the effect of the interactions between the temperature, moisture, and the thermal conductivity of the Jack bean seeds. The surface plot shows that at low temperature $\left(30^{\circ} \mathrm{C}\right)$, it was observed that the thermal conductivity increased with moisture non-linearly, peaked at 20\% (wet basis), and later decreased to a value higher than that of the initial. At elevated temperature $\left(50{ }^{\circ} \mathrm{C}\right)$, thermal conductivity was observed to rise sharply with increased moisture content described by a third other polynomial relationship. It, however, peaked at $15 \%$ moisture content as the highest value of thermal conductivity of Jack beans and then declined (nonlinearly) as the moisture level was further increased to $25 \%$. The trend obtained at $40{ }^{\circ} \mathrm{C}$ was similar to that observed at $50{ }^{\circ} \mathrm{C}$. On the other hand, the thermal conductivity of Jack bean seeds increased nonlinearly with an increase in temperature peaking at $40{ }^{\circ} \mathrm{C}$ and declined as the temperature increased further to $50{ }^{\circ} \mathrm{C}$. At the lowest moisture content (5\% wb), the thermal conductivity value obtained at $30^{\circ} \mathrm{C}$ was observed to be the lowest. Some studies, however, reported a linear relationship between thermal conductivity and moisture content such as Singh and Goswami (2000) for cumin seed, Yang, Sokhansanj, Tang and Winter (2002) for borage seed, Aviara et al. (2008) for Shea nut kernel, Kurozawa, Park and Azonbel (2008) for cashew nut and apple and Gharibzahedi et al. (2013) for red lentil seeds. Gharibzahedi, Etemad, Mirarab-Razi and Foshat (2010) reported that dif- 
ferences in thermal conductivity may be attributed to the variation in seed size, the porosity of sample bulk, and seed chemical composition, such as oil and protein contents. Isa et al. (2014) reported that the thermal energy increases at a higher temperature level as a result of a large amount of moisture present in it and the cellular structure of the product. This thus contributes to high thermal conductivity in the seed as the temperature increases. Table 2 shows the relationships of temperature, moisture content, and thermal conductivity of Jack bean seeds in a third-order polynomial equation. The best fit resulting in an $\mathrm{R}^{2}$ value of 0.9405 was obtained; this implies that the regression equation can be used to satisfactorily describe the relationships between temperature, moisture, and thermal conductivity of Jack bean seeds.

The high value of $\mathrm{R}^{2}$ obtained is also supporting that the relationship between temperature, moisture content, and thermal conductivity of Jack bean seeds was linear and statistically significant $(p<0.05)$ at the third-order polynomial level.

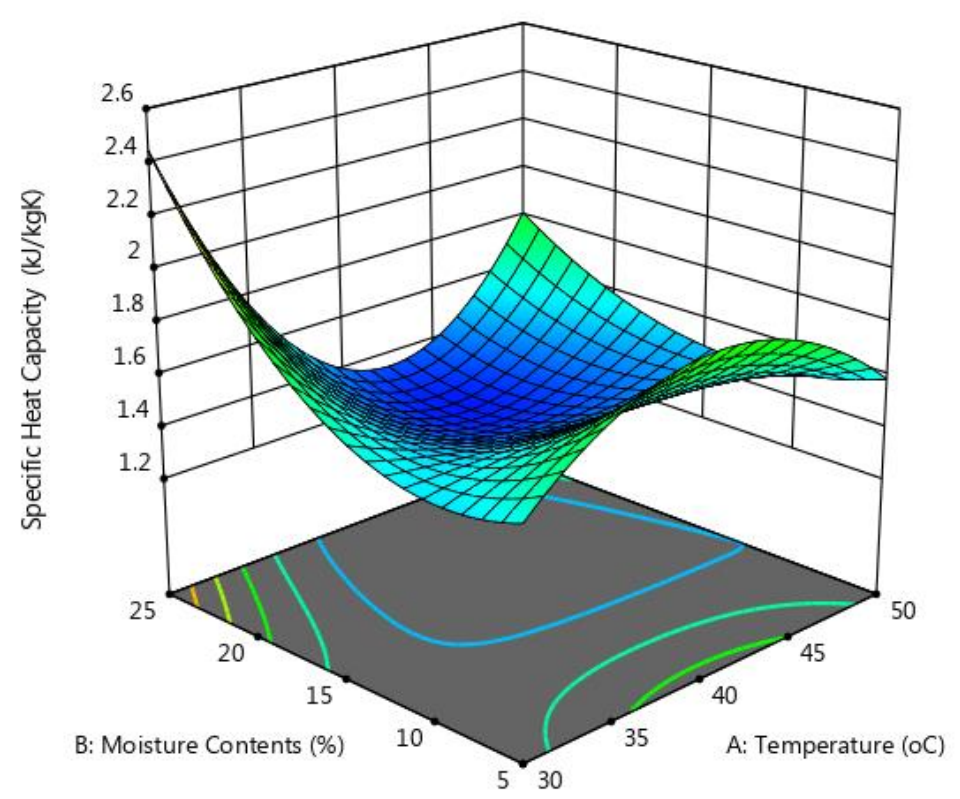

Figure 1. Moisture content and temperature dependent on specific heat capacity of Jack bean seed

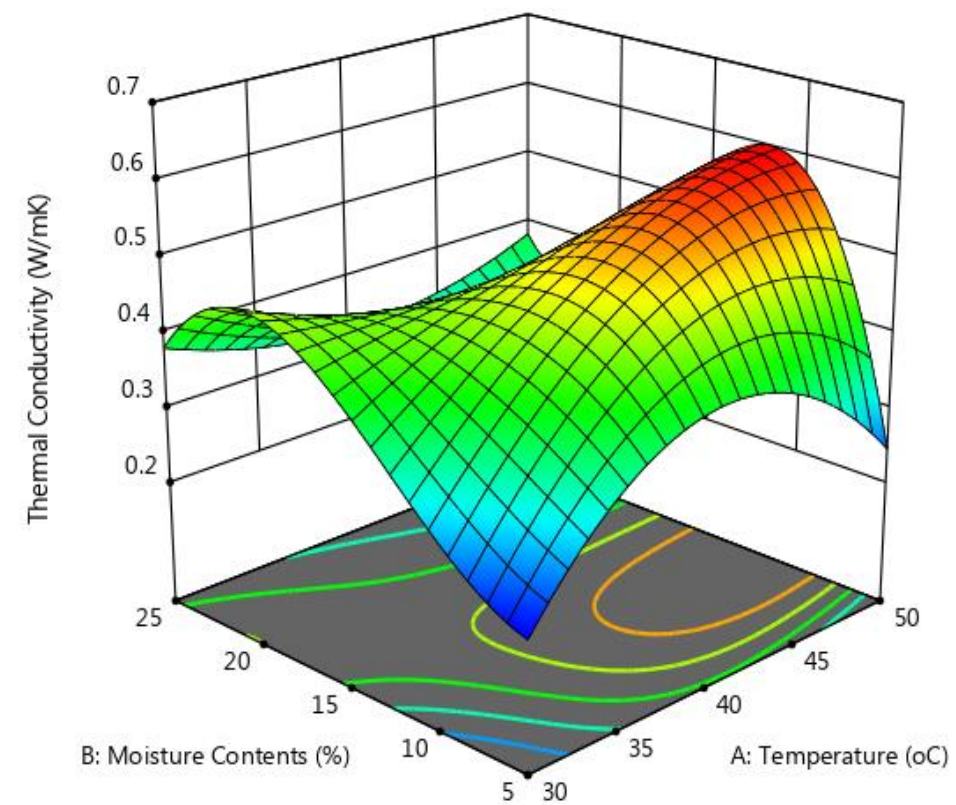

Figure 2. Moisture content and temperature dependence on thermal conductivity of Jack bean seed 


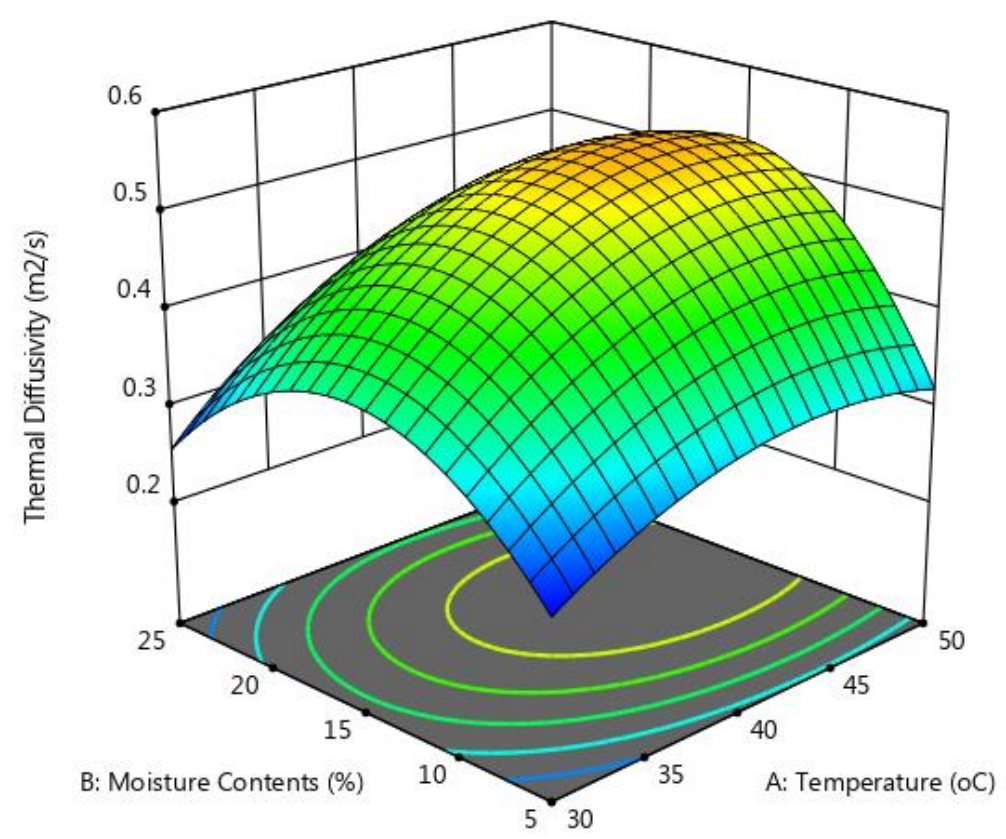

Figure 3. Moisture content and temperature dependent on thermal diffusivity of Jack bean seed

However, a first-order regression and secondorder polynomial was reported by Yang et al. (2002) and Singh and Goswami (2000) for the thermal conductivity of borage seeds and cumin seeds with increasing temperature and moisture content.

The analysis of variance (Table 3 ) indicated that model terms are significant ( $\mathrm{p}$-values less than 0.05 ) and a greater effect of the combined temperature and moisture content than that of the single temperature or moisture on the thermal conductivity of Jack bean seeds. Thus, the moisture content and the temperature influence the thermal conductivity behavior of the seed. This property could be useful for the product before heat treatment for further processing.

\section{Thermal diffusivity of Jack bean seeds}

Results of the thermal diffusivity of Jack bean seeds at different moisture contents and temperatures are presented in Table 1 . The thermal diffusivity varied from 0.25 to $0.41 \times 10^{-7} \mathrm{~m}^{2} / \mathrm{s}$, 0.32 to $0.57 \times 10^{-7} \mathrm{~m}^{2} / \mathrm{s}$ and 0.32 to $0.60 \times 10^{-7}$ $\mathrm{m}^{2} / \mathrm{s}$ at 30,40 and $50{ }^{\circ} \mathrm{C}$ temperatures respectively. These values for thermal diffusivity are relatively higher than those $(0.158$ to 0.205 $\mathrm{x} 10^{-8} \mathrm{~m}^{2} / \mathrm{s}$ ) reported by Abioye et al. (2016) for the Bambara groundnut. However, these values are lower than the ranges $2.32-3.18 \times 10^{-7}, 3.14$
$-2.24 \times 10^{-7} \mathrm{~m}^{2} / \mathrm{s}, 2.369-2.588 \times 10^{-7} \mathrm{~m}^{2} / \mathrm{s}$, and $3.52-4.06 \times 10^{-7} \mathrm{~m}^{2} / \mathrm{s}$ reported by Yang et al. (2002), Aremu and Fadele (2010), Bart-Plange et al. (2012), and Oriola et al. (2016), respectively, for borage seeds, doum palm fruit, cashew kernel, and cooked locust bean seeds. The differences were observed to be due to the method of determinations and agricultural product variations.

Fig. 3 represents the surface plot showing the effect of the interactions between the temperature, moisture and the thermal diffusivity of the Jack bean seeds. The thermal diffusivity of Jack bean seeds increased nonlinearly (quadratic) with moisture content following the same trend as thermal conductivity except that the thermal diffusivity values were lower (Fig. 3 ). Again, the highest diffusivity of Jack bean seeds was obtained at a moisture content of $15 \%$ (wb) across the three temperatures used in the study. Thus, the seeds generally increased nonlinearly in thermal diffusivity with an increase in temperature except that the values were higher at high temperatures. A nonlinear decreasing relationship between thermal diffusivity and moisture content was also reported by Singh and Goswami (2000) for wheat and corn, Bitra, Banu, Ramkrishna, Narender and Womac (2010) for peanut pod and kernel and Aremu and Fadele (2010) for doum palm fruits. How- 
ever, a linear relationship was reported by Aviara and Haque (2001) for Shea nut kernel, Subramanian and Vistwanathan (2003) for guna seed and millet grains, and Tansakul and $\mathrm{Lu}-$ myong (2008) for straw mushroom.

Table 2 shows the temperature, moisture content, and thermal diffusivity relationships of Jack bean seeds in a second-order polynomial equation. The best fit resulting in an $\mathrm{R}^{2}$ value of 0.7997 was obtained. The low value of $R^{2}$ obtained is also supporting that the temperature, moisture content, and thermal diffusivity of Jack bean seeds relationships were not linear and statistically not significant $(p>0.05)$. However, with an $\mathrm{R}^{2}$ value of 0.7997 , the regression equation can be used to describe the relationships between the temperature, moisture, and thermal diffusivity of the Jack bean seeds. Koocheki et al. (2009) reported that $\mathrm{R}^{2}$ should not be less than 0.80 for a well fitted model, while $\mathrm{R}^{2}$ greater than 0.75 was reported acceptable for fitting a model by Chauhan and Gupta (2004). A first-order regression and second-order polynomial was reported by Yang et al. (2002) and Gharibzahedi et al. (2013) to best represent the relationship of the thermal diffusivity of borage seeds and red lentil seeds versus temperature and moisture content. The analysis of variance (Table 3 ) indicated that model terms are significant ( $\mathrm{p}$-values less than 0.05 ) and a greater effect of the combined moisture content than that of the temperature on the thermal diffusivity of Jack bean seeds.

\section{CONCLUSIONS}

From this study, it was found that the thermal properties of Jack bean seeds were moisture and temperature-dependent. The specific heat increased with moisture content at a lower temperature while it reduced with an increase in moisture content at an elevated temperature. The thermal conductivity and thermal diffusivity increased with moisture content up to $15 \%$, beyond which it started declining, especially at temperatures above $30{ }^{\circ} \mathrm{C}$. The study showed that specific heat and thermal diffusivity relationships are best described by the second-order polynomial models whereas thermal conductivity was best described by the third-order polynomial models. These thermal properties of the Jack bean seeds will be helpful in the design of agricultural machines, thermal processes, and equipment needed for storage, drying, heating, and cooling.

\section{REFERENCES}

Abioye, A. O., Adekunle, A. A., \& Agbasi-Ebere, V. (2016). Some moisture-dependent physical and thermal properties of bambara groundnut. IOSR Journal of Environmental Science, Toxicology and Food Technology, 10(10), 65-74. https://doi.org/10.9790/2402-1010016574

Akpapunam, M. A., \& Sefa-Dedeh, S. (1997). Jack bean (Canavalia ensiformis): Nutrition related aspects and needed nutrition research. Plant Foods for Human Nutrition, 50(2), 93-99. https://doi.org/10.1007/bf02436029

Aremu, A. K., \& Fadele, O. K. (2010). Moisture dependence thermal properties of doum palm fruit (Hyphaene thebaica). Journal of Emerging Trends in Engineering and Applied Sciences, 1(2), 199-204.

Arinola, S. O., \& Adesina, K. (2014). Effect of thermal processing on the nutritional, antinutritional, and antioxidant properties of Tetracarpidium conophorum (African walnut). Journal of Food Processing, 1-4. https://doi.org/10.1155/2014/418380

Aviara, N. A., \& Haque, M. A. (2001). Moisture dependence of thermal properties of sheanut kernel. Journal of Food Engineering, 47(2), 109-113. https://doi.org/10.1016/S0260-8774(00)00105-9

Aviara, N. A., Haque, M. A., \& Ogunjimi, L. A. O. (2008). Thermal properties of guna seeds. International Agrophysics, 22(4), 291-297.

Bart-Plange, A., Addo, A., Kumi, F., \& Piegu, A. K. (2012). Some moisture dependent thermal properties of Cashew kernel (Anarcardium occidentale L.). Australian Journal of Agricultural Engineering, 3(2), 65-69.

Bitra, V. S. P., Banu, S., Ramkrishna, P., Narender, G., \& Womac, A. R. (2010). Moisture dependent thermal properties of peanut pods, kernels, and shells. Journal of Food Engineering, 106(4), 503-512. https://doi.org/10.1016/j.biosystemseng.2010.05.016

Carson, J. K. (2017). Use of simple thermal conductivity models to assess the reliability of measured thermal conductivity data. International Journal of Refrigeration, 74, 458-464. https://doi.org/10.1016/j.ijrefrig.2016.10.024

Chakraborty, S. M., \& Johnson, W. H. (1999). Specific heat of flue cured tobacco by differential scanning calorimeter. Transactions of the American Society of Agricultural Engineers, 15(5), 928-931.

Chandrasekar, V., \& Viswanathan, R. (1999). Physical and thermal properties of coffee. Journal of Agricultural Engineering Research, 73(3), 227-234. https://doi.org/10.1006/jaer.1999.0411

Chauhan, B., \& Gupta, R. (2004). Application of statistical experimental design for optimization of alkaline protease production from Bacillus sp. RGR-14. Process Biochemistry, 39(12), 2115-2122. https://doi.org/10.1016/j.procbio.2003.11.002

Embaby, H. E. S. (2010). Effect of heat treatments on certain antinutrients and in vitro protein digestibility of peanut and sesame seeds. Food Science and Technology Research, 17(1), 31-38. https://doi.org/10.3136/fstr.17.31

Gabriel, R. A. O., Akinyosoye, F. A., \& Adetuyi, F. C. (2011). Nutritional composition of Canavalia ensiformis (L.) (Jack beans) as affected by the use of mould starter cultures for fermentation. Trends in Applied Sciences Research, 6, 463-471. 
https://dx.doi.org/10.3923/tasr.2011.463.471

Gharibzahedi, S. M. T., Etemad, V., Mirarab-Razi, J., \& Foshat, M. (2010). Study on some engineering attributes of pine nut (Pinus pinea) to the design of processing equipment. Research in Agricultural Engineering, 56(3), 99-106.

Gharibzahedi, S. M. T., Ghahderijani, M., \& Lajevardi, Z. S. (2013). Specific heat, thermal conductivity and thermal diffusivity of red lentil seed as a function of moisture content. Journal of Food Processing and Preservation, 38(4), 1807-1811. https://doi.org/10.1111/jfpp.12151

Hsu, R. H., Mannapperuma, J. D., \& Singh, R. P. (1991). Physical and thermal properties of pistachios. Journal of Agricultural Engineering Research, 49, 311-321. https://doi.org/10.1016/0021-8634(91)80047-I

Isa, J., Oladele, S. O., \& Akinlade, E. S. (2014). The effect of moisture content on thermal properties of some selected species of Egusi melon (Colocynthis citrillus L.). International Journal of Emerging Technology and Advanced Engineering, 4(4), 580586.

Koocheki, A., Taherian, A. R., Razavi, S. M., \& Bostan, A. (2009). Response surface methodology for optimization of extraction yield, viscosity, hue and emulsion stability of mucilage extracted from Lepidium perfoliatum seeds. Food Hydrocolloids, 23(8), 23692379. https://doi.org/10.1016/j.foodhyd.2009.06.014

Kurozawa, L. W., Park, K. J., \& Azonbel, P. M. (2008). Thermal conductivity and thermal diffusivity of papaya (Carica papaya L.) and cashew apple (Anacardium occidentale L.). Brazilian Journal of Food Technology, 11(1), 78-85.

Marimuthu, M., \& Gurumoorthi, P. (2013). Physicochemical and functional properties of starches from Indian Jack bean (Canavalia ensiformis), an underutilized wild food legume. Journal of Chemical and Pharmaceutical Research, 5(1), 221-225.

Michael, K. G., Sogbesan, O. A., \& Onyia, L. U. (2018). Effect of processing methods on the nutritional value of Canavalia ensiformis Jack bean seed meal. Journal of Food Process Technology, 9(766). doi:10.4172/2157-7110.1000766

Oriola, K. O. (2014). Effects of ageing and moisture content on thermal properties of cassava roots using response surface methodology. International Journal of Applied Agricultural and Apicultural Research, $10(1 \& 2), 54-63$.

Oriola, K. O., Hussein, J. B., Oke, M. O., \& Ajetunmobi, A. (2020). Description and evaluation of physical and moisture dependent thermal properties of Jack bean seeds (Canavalia ensiformis). Journal of Food Processing and Preservation, 45(2) e15166. https://doi.org/10.1111/JFPP.15166

Oriola, K. O., Oke, M. O., Hussein, J. B., \& Adebesin, K. T. (2016). Thermal properties of cooked locust bean (Parkia biglobosa) seeds as affected by temperaturemoisture interactions. Nigerian Journal of Horticultural Science, 21(2016), 48-56.

Osuigwe, D. I., Obiekezie, A. I., \& Onuoha, G. C. (2006). Effects of jackbean seed meal on the intestinal mucosa of juvenile Heterobranchus longifilis. African Journal of Biotechnology, 5(13), 1294-1298. http://dx.doi.org/10.4314/ajb.v5i13.43101

Ranjeet, P., Singh, R. K. R., Varun, T., Mallesha \& Raju, P. S. (2016). Nutritional evaluation of Canavalia ensiformis (Jack bean) cultivated in North East region of India. International Journal of Botany Studies, 1(6), 18-21.

Razavi, S. M. A., \& Taghizadeh, M. (2007). The specific heat of pistachio nuts as affected by moisture content, temperature, and variety. Journal of Food Engineering, 79(1), 158-167. https://doi.org/10.1016/j.jfoodeng.2006.01.039

Sadiku, O. A., \& Bamgboye, I. (2014). Moisture dependent mechanical and thermal properties of Locust bean (Parkia biglobosa). Agricultural Engineering International: CIGR Journal, 16(1), 99-106.

Singh, K. K., \& Goswami, T. K. (2000). Thermal properties of cumin seed. Journal of Food Engineering, 45(4), 181-187. https://doi.org/10.1016/S0260-8774(00)00049-2

Subramanian, S., \& Vistwanathan, R. (2003). Thermal properties of minor millet grains and flours. Biosystems Engineering, 84(3), 289-296.

Tansakul, A., \& Lumyong, R. (2008). Thermal properties of straw mushroom. Journal of Food Engineering, 87, 91-98. https://doi.org/10.1016/j.jfoodeng.2007.11.016

Yang, W., Sokhansanj, S., Tang, J., \& Winter, P. (2002). Determination of thermal conductivity, specific heat, and thermal diffusivity of borage seeds. Biosystems Engineering, 82(2), 169-176. https://doi.org/10.1006/bioe.2002.0066. 


\section{UTICAJ VLAGE I TEMPERATURE NA TOPLOTNA SVOJSTVA SEMENA PASULA (CANAVALIA ENSIFORMIS)}

Oriola K. Olaniyi ${ }^{1}$, Hussein J. Babatunde ${ }^{* 2}$, Oke M. Olanrewaju ${ }^{3}$, Ajetunmobi Abimbola ${ }^{1}$

${ }^{1}$ Ladoke Akintola Univerzitet za tehnologiju, Fakultet inženjerstva i tehnologije, Departman za poljoprivredno inženjerstvo, PMB 4000 Ogbomoso, Savezna država Ojo, Nigerija

${ }^{2}$ Tehnološki univerzitet Modibbo Adama, Poljoprivredni fakultet, Katedra za nauku i tehnologiju hrane, PMB 2076 Jola, Savezna država Adamava, Nigerija

${ }^{3}$ Ladoke Akintola Univerzitet za tehnologiju, Fakultet inženjerstva i tehnologije, Departman za prehrambeno inženjerstvo, PMB 400 Ogbomoso, Savezna država Ojo, Nigerija

Sažetak: Određena su toplotna svojstva (specifični toplotni kapacitet, toplotna provodljivost i toplotna difuzivnost) semena džek pasulja (Canavalia ensiformis), neophodna u projektovanju opreme potrebne za toplotne procese. Toplotna svojstva su određena pri $5,10,15,20$ i $25 \%$ udela vlage i temperaturama na 30,40 i $50^{\circ} \mathrm{C}$ pomoću termalnog analizatora KD2 Pro. Rezultati su pokazali da se specifični toplotni kapacitet kretao od 1,55 do $2,47 \mathrm{~kJ} / \mathrm{kgK}, 1,26$ do $1,84 \mathrm{~kJ} / \mathrm{kgK}$ i 1,32 do $1,99 \mathrm{~kJ} / \mathrm{kgK}$; toplotna provodljivost od 0,21 do $0,47 \mathrm{~W} / \mathrm{mK}, 0,34$ do $0,52 \mathrm{~W} / \mathrm{mK}$ i 0,26 do $0,60 \mathrm{~W} / \mathrm{mK}$ i toplotna difuzivnost od 0,25 do $0,41 \times 10^{-7} \mathrm{~m}^{2} / \mathrm{s}, 0,32$ do $0,57 \times 10^{-7} \mathrm{~m}^{2}$ i $10^{-7} \mathrm{~m}^{2}$ do $0,60 \times 10^{-7}$ $\mathrm{m}^{2} / \mathrm{s}$ na 30,40 , odnosno $50{ }^{\circ} \mathrm{C}$ za proučavane sadržaje vlage. Uticaj temperature i sadržaja vlage nije bio značajan $(\mathrm{p}>0,05)$ na specifičnu toplotu i toplotnu difuzivnost, ali je bio značajan $(\mathrm{p}<0,05)$ na toplotnu provodljivost po modelu polinoma trećeg reda. Utvrđen je nelinearni odnos između tri toplotna parametra i sadržaja vlage unutar proučavanog temperaturnog raspona. Rezultirajući regresioni modeli za toplotna svojstva imali su visoki koeficijent korelacije $\left(\mathrm{R}^{2} \geq 0,7995\right)$, što ukazuje da se mogu koristiti za opisivanje odnosa između temperature, vlage i toplotnih svojstava semena džek pasulja.

Ključne reči: džek pasulj, leguminoze, sadržaj vlage, temperatura, toplotna svojstva, termalni analizator

Received: 5 September 2021 / Received in revised form: 3 December 2021/ Accepted: 7 December 2021

Available online: December 2021

This is an open-access article under the CC BY license (http://creativecommons.org/licenses/by/3.0). 